\title{
The Assessment of Optimistic Self-beliefs: Comparison of the German, Spanish, and Chinese Versions of the General Self-efficacy Scale
}

\author{
Ralf Schwarzer, Judith Bäßler, Patricia Kwiatek and Kerstin \\ Schröder
}

Freie Universität Berlin, Germany

Jian Xin Zhang

Chinese University of Hong Kong

L'auto-efficacité générale est mesurée grâce à une courte échelle composée de dix items. Son usage est très répandu et elle a été adaptée à plusieurs cultures. Cet article compare des versions qui ont été proposées à des étudiants: 430 Allemands, 952 Costariciens et 293 Chinois. Les validités internes sont respectivement de $.84, .81$ et .91 . L'unidimensionnalité de l'échelle est réapparue dans tous les échantillons. L'équivalence items-modèle interlinguistique ne fut que modérément approuvé par des analyses factorielles de confirmation. On a trouvé des différences au niveau des moyennes des scores totaux entre les langues. De plus, une intéraction entre sexe et langue s'est manifestée. Des corrélations avec la dépression, l'anxiété et l'optimisme ont fourni des éléments complémentaires en faveur de la validité de construction.

General self-efficacy is measured by a widely used parsimonious ten-item scale that was developed for use in several cultures. The present paper compares the verions that were examined in samples of 430 German, 959 Costa Rican, and 293 Chinese university students. The internal consistencies were $.84,81$, and 91 , respectively. The unidimensional nature of the scale was replicated in all samples. Multilingual item-pattern equivalence was only moderately supported by confirmatory factor analyses. Mean differences of sum scores between languages were found. Moreover, an interaction between gender and

Requests for reprints should be sent to Professor Dr Ralf Schwarzer, Freie Universität Berlin, Institut of Psychology, Health Psychologie (WE 10), Habelschwerdter Allee 45, 14195 Berlin, Germany. Email:ful1270ap@zedat.fu-berlin.de

This paper was written while the first author was on leave at the Chinese University of Hong Kong. He is grateful for the resources made available to him there. 
language emerged. Correlations with depression, anxiety, and optimism provided some further evidence for construct validity.

\section{INTRODUCTION}

The present article first introduces the theoretical construct of self-efficacy and then describes a brief scale that is designed to measure this construct at the level of a general personality disposition. The original German instrument has been proved reliable and valid in various field studies which are described elsewhere (Schwarzer, 1993). The scale has been translated into many languages, but so far empirical data sets are available only for the German, Spanish, and Chinese versions. This paper compares the psychometric properties for these three versions and examines the crosslanguage equivalence of the instrument. The purpose of the present study is iwofold: to examine whether the theoretical construct of perceived selfefficacy is universal. and to attain psychometrically sound adaptations of the inventory that can be used with Spanish- and Chinese-speaking populations.

\section{The Construct of Perceived Self-efficacy}

Human functioning is facilitated by a personal sense of control. If people believe that they can take action to solve a problem instrumentally, they become more inclined to do so and feel more committed to this decision. The construct of self-efficacy was introduced by Bandura and represents one core aspect of his social-cognitive theory (Bandura, 1977, 1995, in press). Whereas outcome expectancies refer to the perception of the possible consequences of one's action, self-efficacy expectancies refer to personal action control or agency. A person who believes in being able to cause an event can conduct a more active and self-determined life course. This "can do"-cognition mirrors a sense of control over one's environment. It reflects the belief of being able to control challenging environmental demands by means of taking adaptive action. It can be regarded as a self-confident view of one's capability to deal with certain life stressors.

According to theory and research (Bandura, 1995, in press), self-efficacy makes a difference in how people feel, think, and act. In terms of feeling, a low sense of self-efficacy is associated with depression, anxiety, and helplessness. Such individuals also have low self-esteem and harbour pessimistic thoughts about their accomplishments and personal development. In terms of thinking, a strong sense of competence facilitates cognitive processes and performance in a variety of settings, including quality of decision-making and academic achievement. When it comes to preparing action, self-related cognitions are a major ingredient of the motivation process. Self-efficacy levels can enhance or impede motivation. 
People with high self-efficacy choose to perform more challenging tasks. They set themselves higher goals and stick to them. Actions are preshaped in thought, and people anticipate either optimistic or pessimistic scenarios in line with their level of self-efficacy. Once an action has been taken, high self-efficacious persons invest more effort and persist longer than those who are low in self-efficacy. When setbacks occur, they recover more quickly and maintain the commitment to their goals. Self-efficacy also allows people to select challenging settings, explore their environments, or create new environments.

A sense of competence can be acquired by mastery experience, vicarious experience, verbal persuasion, or physiological feedback. Self-efficacy, however, is not the same as positive illusions or unrealistic optimism because it is based on experience and does not lead to unreasonable risk taking. Instead, it leads to venturesome behaviour that is within reach of one's capabilities.

Self-referent thought has become an issue that pervades psychological research in many domains. It has been found that a strong sense of personal efficacy is related to better health, higher achievement, and more social integration. This concept has been applied to such diverse areas as school achievement, emotional disorders, mental and physical health, career choice, and sociopolitical change. It has become a key variable in clinical, educational, social, developmental, health, and personality psychology (Bandura, 1995, in press; Maddux, 1994; Schwarzer, 1992).

\section{The General Self-efficacy Scale}

Self-efficacy is commonly understood as domain-specific; that is, one can have more or less firm self-beliefs in different domains or particular situations of functioning. But some researchers have also conceptualised a generalised sense of self-efficacy. It refers to global confidence in one's coping ability across a wide range of demanding or novel situations. Snyder and collaborators (1991) suggested such a construct, which they coined "hope". They defined hope as a cognitive set that is composed of a reciprocally derived sense of successful agency and pathways. Agency reflects goal-directed determination, whereas pathways refers to planning of ways to meet goals. Agency resembles self-efficacy, whereas pathways resembles outcome expectancies. Skinner, Chapman, and Baltes (1988) have made a similar distinction between agency beliefs and means-endsbeliefs. Other conceptions of generalised self-efficacy have been proposed by Sherer and Maddux (1982) and Wallston (1992). In contrast to dispositional optimism (Scheier \& Carver, 1985, 1992), the theoretical advantage of generalised self-efficacy lies in the explicit assumptions about the causal underpinnings of one's positive outlook on life. Dispositional 
optimism includes all kinds of causes, external and internal, and even chance. Generalised self-efficacy, however, is restricted to one's personal resource beliefs, focusing on competence and disregarding other sources or reasons for optimism (for a detailed discussion of the optimism construct see Schwarzer, 1994).

The general self-efficacy scale aims at a broad and stable sense of personal competence to deal effectively with a variety of stressful situations. The German version of this scale was originally developed by Jerusalem and Schwarzer in 1981, first as a 20 -item version and later as a reduced 10 -item version (Jerusalem \& Schwarzer, 1986, 1992; Schwarzer \& Jerusalem, 1989). It has been used in numerous research projects, where it typically yielded internal consistencies between alpha $=.75$ and .90 . The scale is not only parsimonious and reliable, it has also proved valid in terms of convergent and disriminant validity. For example, it correlates positively with selfesteem and optimism, and negatively with anxiety, depression, and physical symptoms. Previous studies are described in the manual (Schwarzer, 1993), which includes not only the scale in English, German, Spanish, French, Hebrew, Hungarian. Turkish, Czech, and Slovak, but also the results of five studies conducted to examine the psychometric properties of the German version. In addition, norms ( $T$ scores) based on a sample of 1660 German adults are available. The manual describes, among other things, retest reliabilities over one- and two-year periods, and different kinds of validity, such as experimental, criterion-related and predictive validity. All coefficients turned out to be very satisfactory.

The inventory, however, cannot be used as a substitute for domainspecific self-efficacy. Rather. scales should be tailored to the spheres of functioning being explored wherever possible. A distinction could be made here between exploratory and confirmatory research. In innovative largescale field studies governed by a broad range of variables and few specific hypotheses, general constructs have been found useful. An example is our exploratory study on East Germans who migrated to the West when the Berlin wall came down: Over a two-year observation period, initial generalised self-efficacy turned out to be the best single predictor of overall adjustment, as assessed by a number of health and well-being variables (Schwarzer, Hahn, \& Schröder, 1994: Schwarzer \& Jerusalem, 1995). In that case, the unique research context did not allow closer examination of a variety of domain-specific coping outcomes with corresponding specific measures of self-efficacy, although this would have been desirable.

There is a typically better prediction by specific scales if the criterion variables are also measurcd in a spccific manner. For example, if coping with a spider phobia or a maths problem is at stake, domain-specific measures of perceived self-efficacy are better predictors of outcomes than generalised ones. In contrast, if trait anxiety, depression, or similar global constructs are 
to be predicted, generalised constructs are more adequate (Schwarzer, 1993).

\section{Research Question}

The present study aims at examining the psychometric properties of three versions of the General Self-efficacy Scale. This is done with the assumption that self-efficacy is a universal construct that applies to different cultures and can be measured in inventories in different languages. The purpose is to confirm this assumption and provide measures that can be adopted in other countries for collecting further evidence. Three steps are taken to obtain the necessary psychometric data: first, the internal structure of the instrument is scrutinised, which includes item analyses, principal component analyses, and a confirmatory factor analysis to test the equivalence across languages. Second, mean differences between languages and gender are analysed. Third, the construct validity is further explored by correlations with different psychological constructs.

\section{METHOD}

\section{Scale Adaptations}

The original German version of the General Self-efficacy Scale has been found reliable and valid in numerous studies (Schwarzer, 1993). Although previously only a few university students had been part of the sample, the present study includes a new data set of students. Appendix A contains the German version (see Appendix D for the English version of the scale).

The Spanish adaptation (see Appendix B) was based on the German and English versions of the instrument. The adaptation procedure followed the "group consensus model" of several bilingual translators and included a series of back translations and discussions. The aim was not to achieve a literal translation of each item, but rather an adaptation of the construct of self-efficacy. Each item was supposed to include the notion of one's confidence in the personal competence to cope with adverse events.

It was not quite clear whether the Chinese adaptation (Appendix C; based on the English version) would be successful because self-efficacy is an imported "Western" psychological construct, or whether it would be superior to other more indigenous constructs (Bond, 1991; Cheung et al., in press). There is some evidence, however, that it is useful in research on Chinese people. Earley and Christopher $(1993,1994)$, for example, have studied the self-efficacy of Chinese managers. 


\section{Other Measures}

The German and Spanish questionnaires contained identical sets of variables that also included measures for depression, anxiety, and optimism. As a measure of depression, a 16-item depression scale was selected (Zerssen. 1976), with items such as "I feel simply miserable" $(\alpha=.79)$. Anxiety was measured by four items taken from the State-Trait Anxiety Inventory (STAI; Spielberger, 1983), which yielded $\alpha=.74$ in the present sample. Dispositional optimism was measured with the 8-item Life Orientation Test (LOT; Scheier \& Carver, 1985), which contains statements such as "In uncertain times I usually expect the best" $(\alpha=.82)$.

\section{Samples}

The German sample consisted of 430 university students who studied different subjects at two universities in Berlin. There were 250 women with an average age of 23.1 years $(S D=4.2)$ and 180 men with an average age of 24.2 years $(S D=4.4)$. The age difference was statistically significant $(F[1.428]=7.76, P<.01)$. The Spanish-speaking sample consisted of 959 university students from Costa Rica, including 605 women with an average age of 21.3 years $(S D=6.9)$ and 354 men with an average age of 21.0 years $(S D=6.3)$. There was no significant age difference between women and men. The Chinese version was given to 293 first-year undergraduate students at the Chinese University of Hong Kong. These students attended three introductory classes on general psychology, but most of the students did not choose psychology as their major. There were 94 male students with an average age of 19.7 years $(S D=1.4)$ and 199 female students with an average age of 19.5 years $(S D=1.4)$. There was no significant age difference between women and men. Across languages, significant age differences emerged, with the Chinese being the youngest and the Germans being the oldest. This should not have affected the findings because there was no correlation between age and self-efficacy.

\section{Procedure}

In all three studies, the 10 self-efficacy items were randomly inserted in a questionnaire that assessed a number of other constructs to prevent students from recognising the purpose of the items. The data collection was anonymous. There was no payment for filling out the questionnaire. The German data were collected in Berlin in 1993. Administering the entire questionnaire took about half an hour. The data for the Spanish version were collected in 1993 in San José, Costa Rica. This was the same questionnaire as the German one and took about the same time to fill out. The Chinese data were collected in 1994 in Hong Kong. The self-efficacy 
items were randomly inserted in a questionnaire that assessed political stress and healthy nutrition, a total of 35 items that took about five to ten minutes to complete.

\section{RESULTS}

The results section will focus first on the internal structure of the instrument to assess the psychometric properties for each of the three language versions. Then, mean differences and further evidence for validity will be examined.

\section{Item Characteristics and Reliability}

Item analyses were carried out separately for each version of the scale. Each item had a response range from one to four. Item means and corrected item-total correlations are given in Table 1 . All coefficients turned out to be satisfactory. No improvement was possible by eliminating items. The internal consistency of Cronbach's $\alpha=.91$ was excellent for the Chinese version. Those of .84 and .81 for the German and Spanish versions were satisfactory, considering that the scale contained only 10 items.

\section{Principal Components Analyses}

In previous German studies the scale was homogeneous. To study this scale characteristic, a principal components analysis was computed separately for each language version. In the German sample, the first three eigenvalues were $4.06,0.96$, and 0.82 . Thus, only one general factor was extracted that accounted for $41 \%$ of the total variance. For the Spanish version, the first three eigenvalues were $3.91,1.00$, and 0.90 . A one-factor solution with $39 \%$ of variance accounted for was suitable. In the Chinese sample, the first three eigenvalues were $5.49,0.84$, and 0.74 . Again, this was a replication of unidimensionality with the first factor accounting for $55 \%$ of the variance.

\section{Psychometric Equivalence of the Instrument Across Languages}

It was demonstrated that the scale was reliable as well as homogeneous or unidimensional in all three versions. This indicates a certain degree of cross-language psychometric equivalence. However, the degree to which equivalence is given depends also on the constraints that are imposed on the comparison procedure. If the aim is to construct an instrument that is equivalent on an item-by-item basis, it is necessary to test the congruence of the item pattern across groups. This can be performed by multigroup confirmatory factor analysis (CFA). A very constrained model uses the parameter estimates for the first sample as a standard and holds only if the 
TABLE 1

Item Means and Corrected Item-Total Correlations for 10 Self-efficacy Items in German, Spanish, and Chinese

\begin{tabular}{ccccccc}
\hline & \multicolumn{2}{c}{$\begin{array}{c}\text { Berlin } \\
(n=420)\end{array}$} & \multicolumn{2}{c}{$\begin{array}{c}\text { Costa Rica } \\
(n=943)\end{array}$} & \multicolumn{2}{c}{$\begin{array}{c}\text { Hong Kong } \\
(n=293)\end{array}$} \\
\hline Item & Mean & Correlation & Mean & Correlation & Mean & Correlation \\
\hline 1 & 2.82 & .39 & 3.09 & .25 & 2.86 & .66 \\
2 & 3.18 & .45 & 3.74 & .36 & 2.40 & .46 \\
3 & 2.66 & .50 & 3.17 & .35 & 1.96 & .53 \\
4 & 2.38 & .57 & 3.32 & .56 & 2.34 & .76 \\
5 & 2.93 & .61 & 3.21 & .61 & 2.24 & .74 \\
6 & 2.69 & .67 & 3.34 & .63 & 2.81 & .72 \\
7 & 3.06 & .54 & 3.22 & .64 & 2.54 & .76 \\
8 & 2.33 & .50 & 3.64 & .51 & 2.46 & .59 \\
9 & 2.81 & .56 & 3.08 & .54 & 2.72 & .69 \\
10 & 2.92 & .47 & 3.34 & .52 & 2.19 & .72 \\
\hline alpha & \multicolumn{7}{c}{.84} & \multicolumn{7}{c}{.81} & & .91 & \\
\hline
\end{tabular}

parameters of the other two groups do not differ from this standard (Hocevar \& El-Zahhar, 1985, 1992).

The model was tested with the LISREL 8 program (Jöreskog \& Sörbom, 1993). Input was a correlation matrix of the 10 observed variables for each culture. Accordingly, the parameters were estimated by the unweighted least squares method. The model fit was evaluated in terms of chi-square, root mean square residuals (RMR), and various goodness of fit indices. The chi-square divided by the degrees of freedom can be seen as a less biased fit estimate $\left(\chi^{2} / d f\right)$ than the chi-square itself because it is dependent on sample size. This quotient should be small, and values below three are considered to be satisfactory (Bentler, 1980; Bollen, 1989; Bollen \& Long, 1993; Byrne, 1990 ). The root mean square residual should be very small with values below .05 being desirable. The goodness of fit index (GFI) should be above .92 . The same applies to the adjusted GFI (AGFI; adjusted for degrees of freedom). These are rough fit indicators only. A more comprehensive assessment includes further fit indices as well as a careful inspection of the parameter estimates, accounted variance, and modification indices.

First, a one-dimension confirmatory factor analysis was computed for each sample. This yielded the factor loadings in the first three columns of Table 2. The fit indices turned out to be excellent, which confirmed the unidimensionality of the instrument. For the German sample the fit was $\chi^{2}=31.56 \quad(35 d f, \quad P=.64), \quad \chi^{2} / d f=.90, \quad \mathrm{RMR}=.037, \quad \mathrm{GFI}=.99$, and AGFI $=.99$. For the Spanish version the fit was $\chi^{2}=59.53$ (35df, $P=.006$ ), $\chi^{2} / d f=1.70, \mathrm{RMR}=.033, \mathrm{GFI}=.99$, and $\mathrm{AGFI}=.99$. Although the $\chi^{2}$ value was significant here, the model still fitted very well. The obvious reason for 
TABLE 2

Factor Loadings of the 10 Self-efficacy Items (LISREL Unweighted Least Squares Parameter Estimates) in Group-specific and Multigroup Confirmatory Factor Analyses

\begin{tabular}{ccccc}
\hline Item & German & Spanish & Chinese & Common Metric \\
\hline 1 & .42 & .29 & .70 & .40 \\
2 & .48 & .39 & .49 & .43 \\
3 & .55 & .38 & .56 & .46 \\
4 & .63 & .63 & .81 & .66 \\
5 & .67 & .68 & .78 & .70 \\
6 & .75 & .72 & .76 & .73 \\
7 & .60 & .73 & .81 & .71 \\
8 & .54 & .56 & .62 & .57 \\
9 & .62 & .61 & .74 & .64 \\
10 & .52 & .58 & .75 & .60 \\
\hline
\end{tabular}

this undesirable significance is the large sample size of the Costa Rican student group. For the Chinese sample the fit was $\chi^{2}=27.09$ (35df, $P=.83$ ), $\chi^{2} / d f=.77, \mathrm{RMR}=.041, \mathrm{GFI}=.99$, and $\mathrm{AGFI}=.99$.

So far, this CFA replicated the earlier principal component analyses at a more sophisticated level. The main purpose for application of CFA, however, was the very strict test of cross-language equivalence which was done by a multigroup analysis. The German sample data were given as the standard because the instrument was originally developed in German, and its validity is mainly given by studies with that particular version. The other two data sets were constrained to produce identical unweighted least squares parameter estimates. That is, technically the lambda $\mathrm{X}$ and theta delta matrices were to be the same as for the first group if this model holds (invariance assumption). The goodness of fit for the constrained three-group model turned out to be $\chi^{2}=583.3$ (145 df, $P<.001$ ), $\chi^{2} / d f=4.01$, $\mathrm{RMR}=.15$, and GFI $=.93$. This is clearly less favourable than the fit for the three separate models given earlier. It indicates that the assumption of an item-by-item cross-cultural equivalence is not very well supported by the data.

By the same procedure, a common metric was provided. The factor loadings for the 10 items, for the three groups combined, are given in column 4 of Table 2.

\section{Scale Characteristics}

The 10-item sum score had a theoretical range from 10 to 40 , due to the 1 to 4 response format. For the German version the mean was $27.8(S D=4.5$, $N=420$ ). The distribution was somewhat negatively skewed (skewness $=-.49$ ), and the Kolmogorov-Smirnov test indicated deviations 
from normality $(z=2.02, P<.01)$. The mean in the Costa Rican sample was $33.2(S D=4.43, N=943$ ), also with a skewed distribution (skewness $=-.71$, $z=2.78 . P<.01$ ). For the Chinese version the mean was 24.56 and the standard deviation was $5.31(N=293)$. The sum scores were normally distributed according to the one-sample test by Kolmogorov-Smirnov $(z=.98, P=.30)$. Figure 1 depicts the relative frequency distributions for the three samples.

\section{Language and Gender Differences}

There are obviously mean differences between these three data sets in terms of culture and gender. A two-way factorial analysis of variance (three levels of language and two levels of gender) was computed to determine these effects. Due to some missing values, the analysis was based on only 1653 persons. Table 3 contains the cell means, standard deviations, and cell sizes.

There was a significant main effect for language $(F[2,1647]=400.39$, $P<.001$, partial eta $\left.{ }^{2}=.33\right)$, a significant main effect for gender $(F[1,1647]=$ $45.04, P<.001$, partial eta $\left.{ }^{2}=.03\right)$, and a significant interaction effect $(F[2$, $1647]=10.47, P<.001$, partial eta $\left.{ }^{2}=.01\right)$. Significant gender differences emerged in the Chinese sample $(t=5.1, d f=291, P<.01)$ and in the German sample $(t=3.8, d f=417, P<.01)$, but not in the Costa Rican sample $(t=1.3, d f=939, P=.20)$. Figure 2 illustrates that women in Hong

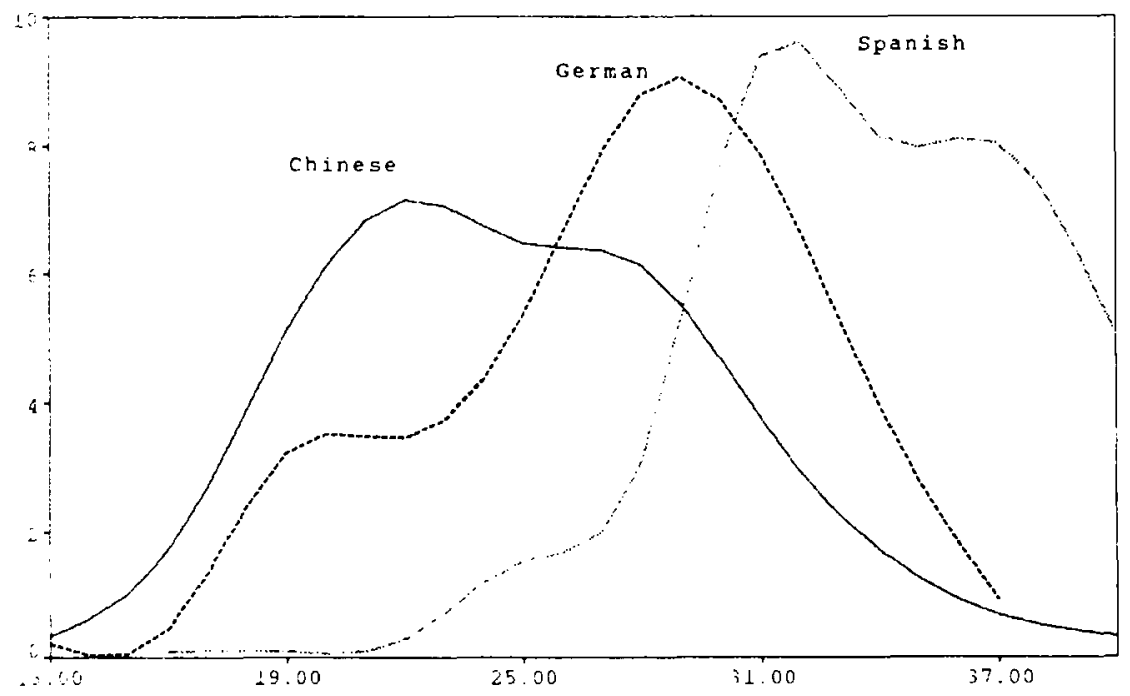

FIG. 1. Relative frequency distributions of the sum score of the self-efficacy scale in each culture. 
TABLE 3

Self-efficacy Scale Means and Standard Deviations Broken Down by Sample and Gender

\begin{tabular}{lllll}
\hline Sample & Gender & Mean & $S D$ & $n$ \\
\hline Germany & Women & 27.15 & 4.45 & 247 \\
& Men & 28.82 & 4.27 & 172 \\
Costa Rica & Women & 33.06 & 4.58 & 595 \\
& Men & 33.44 & 4.14 & 346 \\
Hong Kong & Women & 23.52 & 5.22 & 199 \\
& Men & 26.76 & 4.84 & 94 \\
\hline
\end{tabular}

Kong and Germany obtained on average lower self-efficacy scores than men. It also shows that Costa Rican students attained the highest mean levels and Hong Kongese students the lowest.

\section{Validity}

Self-efficacy in the German sample correlated with depression $r=-.52$, anxiety $r=-.60$, and optimism $r=.55$. In the Costa Rican sample it was associated with the same variables $r=-.42, r=-.43$, and $r=.57$, respectively. This pattern of correlations indicates sufficient discriminant

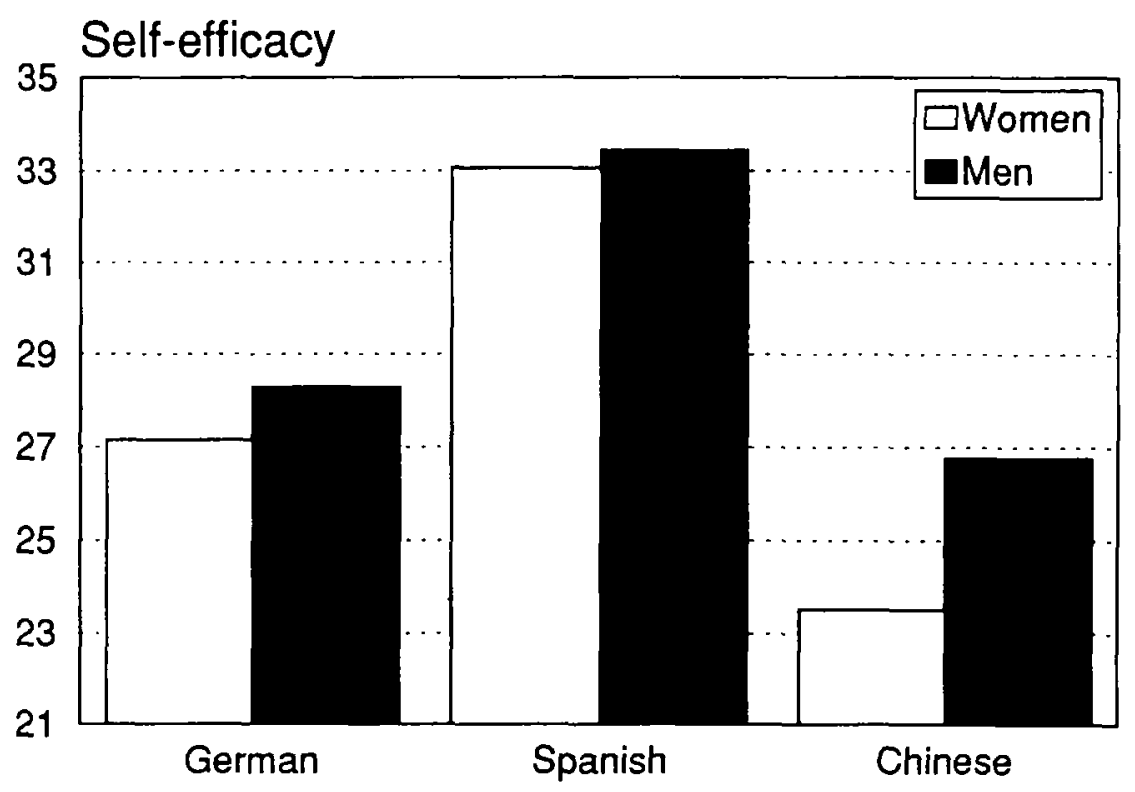

FIG. 2. Average self-efficacy scores for women and men in Germany, Costa Rica, and Hong Kong. 
validity and is in line with self-efficacy theory (Bandura, in press). Depression and anxiety as negative emotional traits need to be associated negatively with self-efficacy. Individuals who trust their competence to deal with adverse events cannot be severely depressed and anxious at the same time. The construct of dispositional optimism is closely related to the general self-efficacy construct, although it is not constrained to the notion of personal action resources. Thus, a moderate to high positive correlation has to be expected. The similarity between the obtained patterns of coefficients in the German and in the Spanish version points to some degree of cross-language validity of the instrument. Also, this is in line with previous findings within different German samples (Schwarzer, 1993).

Further validity is indicated by the correlation of the scale with some other items in the Chinese multipurpose questionnaire. Some questions pertained to the stresses that people in Hong Kong might experience as they anticipate the transition from British to Chinese rule in 1997. There were two items that were designed to assess specific self-efficacy to deal with this stressful political transition: the first item was "I certainly can meet the challenges that are implied for me in the upcoming Chinese rule", and the second "I am confident that I can deal successfully with the challenges and threats that occur as the government changes in Hong Kong". The first item correlated with general self-efficacy $r=.48$, the second $r=.44$. General self-efficacy need not necessarily be closely associated with a specific self-efficacy. but if it does so it may indicate validity. In sum, the three language versions of the scale can be considered psychometrically sound and, thus, they constitute adequate versions that can be used in subsequent research designed for further validation.

\section{DISCUSSION}

The present study focused on a comparison of two new scale adaptations (Spanish and Chinese) with the well-established German original version. It was found that in all three languages the psychometric properties were satisfactory. Reliability, item-total correlations, and factor loadings indicated that the General Self-efficacy Scale can be seen as homogeneous and unidimensional. By achieving these characteristics it has been demonstrated that the self-efficacy construct tends to be a universal one, claiming construct validity across very different cultures. However, this is mainly a psychometric study, not a truly cross-cultural one. Psychometric equivalence across languages can be seen as a prerequisite for subsequent cross-cultural studies that also take indigenous characteristics of the specific cultures into account.

The Chinese version is psychometrically the best one, with an internal consistency of .91 and a normal frequency distribution. The low mean levels 
of perceived self-efficacy could be interpreted as a cultural difference, as the Chinese are regarded as less individualistic than Westerners (Bond, 1991, 1994; Earley \& Christopher, 1993, 1994). Thus, it would be interesting to compare their scores in future studies with corresponding levels of collective self-efficacy (Bandura, 1995). On the other hand, the present data base is not representative for Chinese students or even for the Chinese population. The students in Hong Kong perceive themselves neither as typically Hong Kongese nor as typically Chinese. Bond (1994) has found that the self-ratings of these students form an isolated category that is distinct from the perceived traditional Chinese, contemporary Chinese, or Westerners. The high educational level, the Western influence, and the Chinese societal values may jointly contribute to the establishment of an identity that is unique for this particular cohort. Thus, any generalisation of test results from the present sample to other segments of the Chinese population is premature. The lack of generalisability also applies, strictly speaking, to the Costa Rican samples because these were large samples of convenience. University students constitute an elite that has better opportunity structures and more options for environmental control than the majority of the population. But in comparing students across countries instead of within countries, no selection bias is expected. Thus, there is no reason to suspect that these data are severely biased. In particular, there is no reason to distrust the German findings, as multiple samples from different cohorts have yielded similar results (see Schwarzer, 1993).

A more general question is how to establish psychometric equivalence across languages by using advanced methodology. This can be seen as a gradual process of continuous replication of psychometric findings that add to construct validity within and across cultures. An ambitious quantitative approach to this problem lies in the specification of a measurement model that refers to more than one group simultaneously. For example, the model could simply postulate unidimensionality of the inventory in each sample. In a much more constrained manner, the model could state that all factor loadings and measurement errors should be the same across groups. It is the latter research question that has been applied in the present study. In order to determine whether such a model fits the data from several cultures, a multigroup confirmatory factor analysis was computed. It turned out that the model fit was not fully satisfactory. The results did not support the assumption very well that the factor loading pattern is exactly the same across cultures. Does this finding reject the assumption of cross-language equivalence? Certainly not, unless one demands a strict item-by-item equivalence of instruments. The translators had been asked to understand the theoretical construct of self-efficacy and to find meaningful adaptations instead of making literal translations of each item. Under such circumstances, the parameter estimates for the item pattern might be 
different from sample to sample, but the underlying construct of self-efficacy might still be assessed validly within each sample.

A related problem arises by inspection of the mean differences between groups. Why have the Costa Rican students the highest self-efficacy means and the Chinese students the lowest? It is assumed that the Chinese have higher collective self-efficacy than "individualistic" self-efficacy (Bond, 1991. 1994). However, this difference could be also be an undesired side-effect of the instrument development. Perhaps the Spanish items are "easier" than the Chinese items. This is a general problem of all crosscultural studies using multilanguage versions of the same inventory. The endorsement of items is multiply determined. Among the factors that influence the endorsements are characteristics of the cultural context, those of item wording, and numerous biases, such as situational circumstances of test administration.

The same problem pertains to the mean differences between men and women. In most of the previous German samples under study there were no gender differences (Schwarzer, 1993), but in the present sample of German university students, men had higher self-efficacy than women. The same was found in the Chinese sample. In no study yet have the women obtained higher self-efficacy than men. This need not be a disadvantage of the instrument or the construct itself. Remember that, for example, anxiety, as measured by different instruments, is usually higher for women than for men. Research is needed to examine whether the construct of general self-efficacy favours men, or whether the present inventory contains a "male bias", and why gender differences emerge in some instances and in others not.

The present analysis was restricted to samples of university students to assure some homogeneity of the populations under study. Several other samples. including senior citizens, have also responded to the questionnaire, but so far only in German. Therefore, they were not considered here. Further German validation studies can be found in the scale manual (Schwarzer, 1993).

In spite of the limitations that are typical for cross-cultural studies, the psychometric properties of the parsimonious General Self-efficacy Scale are now established for three languages. It is suggested that large-scale field studies may also include these 10 items for enrichment purposes. For example, it could replace dispositional optimism or self-esteem scales that are often included in an exploratory manner. Self-esteem is frequently used as a global indicator of mental health, personal coping resources, and emotional adjustment without being theoretically elaborated. Compared to global self-esteem, perceived self-efficacy is a well-established construct, based on social-cognitive theory that has high explanatory and operative power (Bandura, in press). That is, it not only explains human functioning 
quite well, it is also easily alterable by interventions. The General Self-efficacy Scale can be used in screening people at risk for coping deficiencies, which can set the stage for subsequent prevention programmes.

Manuscript received April 1995

Revised manuscript received December 1995

\section{REFERENCES}

Bandura, A. (1977). Self-efficacy: Toward a unifying theory of behavioral change. Psychological Review, 84, 191-215.

Bandura, A. (Ed.) (1995). Self-efficacy in changing societies. New York: Cambridge University Press.

Bandura, A. (in press). Self-efficacy: The exercise of control. New York: Freeman.

Bentler, P.M. (1980). Multivariate analysis with latent variables: Causal modeling. Annual Review of Psychology, 31, 419-456.

Bollen. K.A. (1989). Structural equations with latent variables. New York: Wiley.

Bollen, K.A., \& Long. J.S. (1993). Testing structural equation models. Newbury Park. CA: Sage.

Bond. M.H. (1991). Beyond the Chinese face. Insights from psychology. Hong Kong: Oxford University Press.

Bond. M.H. (1994). Between the yin and the yang: The identity of the Hong Kong Chinese. Hong Kong: Chinese University Bulletin (Supplement 31).

Byrne, B.M. (1990). A primer of LISREL. New York: Springer.

Cheung. F.M., Leung, K., Fan, R.M., Song, W.Z., Zhang, J.X., \& Zhang, J.P. (in press). Development of the Chinese Personality Assessment Inventory (CPAI). Journal of Cross-Cultural Psychology.

Earley. P., \& Christopher, N. (1993). East meets West meets Mideast: Further exploration of collectivistic and individualistic work groups. Academy of Management Journal, 36(2), 319-348.

Earley, P., \& Christopher, N. (1994). Cultural effects of training on self-efficacy and performance. Administrative Science Quarterly, 39(1), 89-117.

Hocevar, D., \& El-Zahhar, N. (1985). Test anxiety in the USA and Egypt: A paradigm for investigating psychometric characteristics across cultures. In H.M. van der Ploeg. R. Schwarzer, \& C.D. Spielberger (Eds.), Advances in test anxiety research (Vol. 4, pp.202213). Lisse. The Netherlands: Swets \& Zeitlinger.

Hocevar. D.. \& El-Zahhar. N. (1992). Cross-cultural differences in test anxiety: Establishing transliteral equivalence. In K.A. Hagtvet \& T.B. Johnsen (Eds.), Advances in test anxiety research (Vol. 7. pp.48-61). Lisse, The Netherlands: Swets \& Zeitlinger.

Jerusalem, M.. \& Schwarzer, R. (1986). Selbstwirksamkeit [Self-efficacy]. In R. Schwarzer (Ed.), Skalen zur Befindlichkeit und Persönlichkeit. Research Report No. 5 (pp.15-28). Berlin: Freie Universität, Institut für Psychologie.

Jerusalem. M., \& Schwarzer, R. (1992). Self-efficacy as a resource factor in stress appraisal processes. In R. Schwarzer (Ed.), Self-efficacy: Thought control of action (pp.195-213). Washington, DC: Hemisphere.

Jöreskog. K.G., \& Sörbom, D. (1993). LISREL 8.03. Chicago: Scientific Software International.

Maddux. J. (Ed.) (1994). Self-efficacy, adaptation, and adjustment: Theory, research, and application. New York: Plenum Press.

Scheier. M.F., \& Carver, C.S. (1985). Optimism, coping, and health: Assessment and implications of generalized outcome expectancies. Health Psychology. 4, 219-247. 
Scheier, M.F., \& Carver, C.S. (1992). Effects of optimism on psychological and physical well-being: Theoretical overview and empirical update. Cognitive Therapy and Research, 16. 201-228.

Schwarzer. R. (Ed.) (1992). Self-efficacy: Thought control of action. Washington, DC: Hemisphere.

Schwarzer, R. (1993). Measurement of perceived self-efficacy. Psychometric scales for crosscultural research. Berlin, Germany: Freie Universität Berlin.

Schwarzer. R. (1994). Optimism, vulnerability, and self-beliefs as health-related cognitions: A systematic overview. Psychology and Health: An International Journal, 9. 161-180.

Schwarzer, R., Hahn. A.. \& Schröder, H. (1994). Social integration and social support in a life crisis: Effects of macrosocial change in East Germany. American Journal of Community Psychology, 22. 685-706.

Schwarzer, R., \& Jerusalem. M. (1989). Erfassung leistungsbezogener und allgemeiner Kontroll- und Kompetenzerwartungen [Assessment of performance-related and general control and competence beliefs]. In G. Krampen (Ed.), Diagnostik von Attributionen und Kontrolliuberzeugungen (pp.127-133). Göttingen. Germany: Hogrefe.

Schwarzer, R., \& Jerusalem. M. (1995). Optimistic self-beliefs as a resource factor in coping with stress. In S.E. Hobfoll \& M.W. deVries (Eds.), Extreme stress and communities: Impact and intervention (pp.159-177). Dordrecht. The Netherlands: Kluwer.

Sherer. M.. \& Maddux. J.E. (1982). The self-efficacy scale: Construction and validation. Psychological Reports. 51.663-671.

Skinner. E.A.. Chapman, M.. \& Baltes. P. (1988). Control, means-ends. and agency beliefs: A new conceptualization and its measurement during childhood. Journal of Personaliry and Social Psychology. 54, 117-133.

Snyder, C.R., Harris, C., Anderson, J.R., Holleran, S.A., Irving, L.M., Sigmon, S.T., Yoshinobu, L.. Gibb. J., Langelle, C., \& Harney, P. (1991). The will and the ways: Development and validation of an individual-differences measure of hope. Journal of Personality and Social Psychology. 60. 570-585.

Spielberger. C.D. (1983). Manual for the State-Trait Anxiety Inventory (STAI). Palo Alto, CA: Consulting Psychologists Press.

Wallston. K.A. (1992). Hocus-pocus, the focus isn't strictly on locus: Rotter's social learning theory modified for health. Cognitive Therapy and Research. 16. 183-199.

Zerssen, D.V. (1976). Depressivitäts-Skala (D-S) [Depressiveness scale (D-S)]. Weinheim, Germany: Beltz. 


\section{APPENDIX A (GERMAN) \\ Generalisierte Kompetenzerwartung}

1) Wenn mir jemand Widerstand leistet, finde stimmt stimmt stimmt stimmt nicht kaum eher genau ich Mittel und Wege, mich durchzusetzen. 1

23

4

2) Die Lösung schwieriger Probleme gelingt mir immer, wenn ich mich darum bemühe.

1

2

34

3) Es bereitet mir keine Schwierigkeiten, meine Absichten und Ziele zu verwirklichen.

4) In unerwarteten Situationen weiß ich immer, wie ich mich verhalten soll.

5) Auch bei überraschenden Ereignissen glaube ich, daB ich gut damit zurechtkommen werde.

1

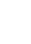

2

3

4

1

2

3

4

6) Schwierigkeiten sehe ich gelassen entgegen, weil ich mich immer auf meine Fähigkeiten verlassen kann.

1

7) Was auch immer passiert, ich werde schon klarkommen.

2

34

8) Für jedes Problem finde ich eine Lösung.

9) Wenn ich mit einer neuen Sache konfrontiert werde, wei $B$ ich, wie ich damit umgehen kann.

1

$\begin{array}{llll}1 & 2 & 3 & 4\end{array}$

1

2

10) Wenn ich mit einem Problem konfrontiert werde, habe ich meist mehrere Ideen, wie ich damit fertig werde. 


\section{APPENDIX B (SPANISH) \\ Autoeficacia Generalizada}

incorrecto apenas más bien cierto
cierto cierto

1) Puedo encontrar la manera de obtener lo que quiero aunque alguien se me oponga.

2) Puedo resolver problemas difíciles si me esfuerzo lo suficiente.

1

23

4

3) Me es fácil persistir en lo que me he

propuesto hasta llegar a alcanzar mis metas.

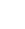

$\begin{array}{lll}2 & 3 & 4\end{array}$

4) Tengo confianza en que podria manejar eficazmente acontecimientos inesperados.

5) Gracias a mis cualidades y recursos puedo superar situaciones imprevistas.

$\begin{array}{llll}1 & 2 & 3 & 4\end{array}$

6) Cuando me encuentro en dificultades puedo permanecer tranquilo/a porque cuento con las habilidades necesarias para manejar situaciones difíciles.

7) V'enga lo que venga, por lo general soy capaz de manejarlo.

1

2

$\begin{array}{llll}1 & 2 & 3 & 4\end{array}$

Puedo resolver la mayoría de los problemas si me esfuerzo lo necesario.

$\begin{array}{lll}2 & 3 & 4\end{array}$

9) Si me encuentro en una situación difícil. generalmente se me ocurre qué debo hacer

10) AJ tener que hacer frente a un problema. generalmente se me ocurren varias alternativas de cómo resolverlo.

1




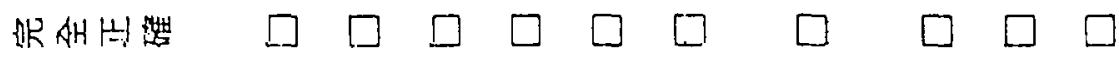

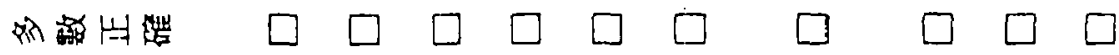

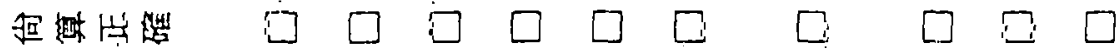

织财长怕些

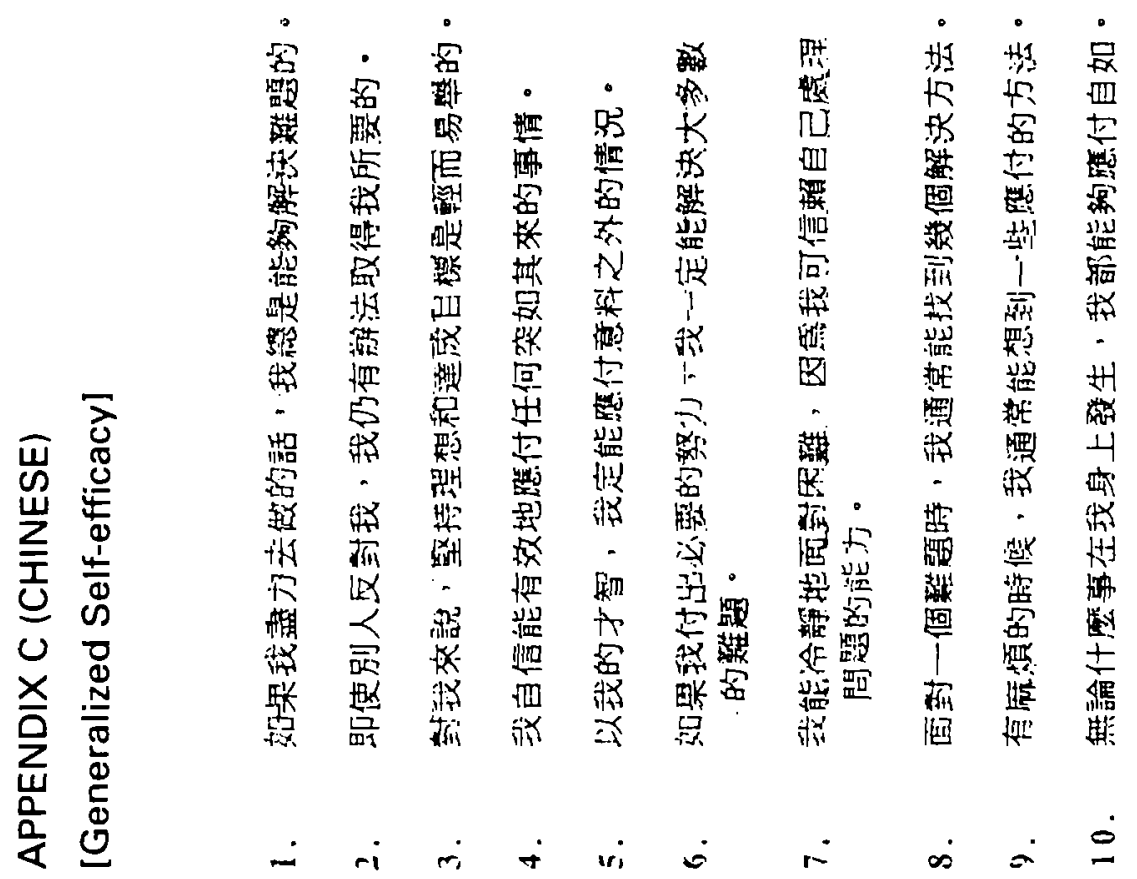




\section{APPENDIX D (ENGLISH)}

\section{Generalized Self-efficacy}

\begin{tabular}{|c|c|c|c|c|c|}
\hline & & $\begin{array}{l}\text { Not at all } \\
\text { True }\end{array}$ & $\begin{array}{l}\text { Barely } \\
\text { True }\end{array}$ & $\begin{array}{l}\text { Moderately } \\
\text { True }\end{array}$ & $\begin{array}{c}\text { Exactly } \\
\text { True }\end{array}$ \\
\hline 1) & $\begin{array}{l}\text { I can always manage to solve difficult } \\
\text { problems if I try hard enough. }\end{array}$ & 1 & 2 & 3 & 4 \\
\hline 2) & $\begin{array}{l}\text { If someone opposes me. I can find means } \\
\text { and ways to get what I want. }\end{array}$ & 1 & 2 & 3 & 4 \\
\hline 3) & $\begin{array}{l}\text { It is easy for me to stick to my aims and } \\
\text { accomplish my goals. }\end{array}$ & 1 & 2 & 3 & 4 \\
\hline 4) & $\begin{array}{l}\text { I am confident that I could deal efficiently } \\
\text { with unexpected events. }\end{array}$ & 1 & 2 & 3 & 4 \\
\hline 5) & $\begin{array}{l}\text { Thanks to my resourcefulness, I know how } \\
\text { to handle unforeseen situations. }\end{array}$ & 1 & 2 & 3 & 4 \\
\hline 6) & $\begin{array}{l}\text { I can solve most problems if I invest the } \\
\text { necessary effort. }\end{array}$ & 1 & 2 & 3 & 4 \\
\hline 7) & $\begin{array}{l}\text { I can remain calm when facing difficulties } \\
\text { because I can rely on my coping abilities. }\end{array}$ & 1 & 2 & 3 & 4 \\
\hline 8) & $\begin{array}{l}\text { When I am confronted with a problem, I } \\
\text { can usually find several solutions. }\end{array}$ & 1 & 2 & 3 & 4 \\
\hline 9) & $\begin{array}{l}\text { If I am in a bind, I can usually think of } \\
\text { something to do. }\end{array}$ & 1 & 2 & 3 & 4 \\
\hline 10) & $\begin{array}{l}\text { No matter what comes my way, I'm } \\
\text { usually able to handle it. }\end{array}$ & 1 & 2 & 3 & 4 \\
\hline
\end{tabular}

